\title{
Ocena kosztów gospodarki skałą płonną w funkcji zmiennego poziomu współczynnika uzysku węgla netto na przykładzie kopalni węgla kamiennego
}

\section{Wprowadzenie}

Istotnym aspektem prawidłowo prowadzonego procesu zarządzania w kopalniach jest ocena potencjału złoża, jego optymalnego udostępnienia, zagospodarowania i eksploatacji (Magda i in. 2002).

W ten zakres zagadnień włącza się niewątpliwie właściwie rozumiany „problem” kosztów gospodarki skałą płonną na dole kopalń, która towarzyszy procesowi wydobycia kopalin użytecznych. W większości przypadków odpady - produkt uboczny procesu wydobywczego - nie stanowią przedmiotu sprzedaży; generują koszty, których poziom uznaje się w skali całego górnictwa, w szczególności górnictwa węglowego za duży i ciągle rosnący (Góralczyk red. 2011).

W tabeli 1 i na rysunku 1 przedstawiono kierunki wykorzystania skały płonnej na tle wydobycia węgla kamiennego w Polsce na latach 2003-2013.

Analizując dane o gospodarce odpadami w sektorze węgla kamiennego w Polsce w latach 2003-2013 można wyciągnąć następujące wnioski główne:

- w latach 2007-2013 wyraźnie spada wydobycie węgla, z poziomu 87,2 mln Mg do 76,5 $\mathrm{mln} \mathrm{Mg}$ (tab. 1),

* Dr inż., Instytut Gospodarki Surowcami Mineralnymi i Energią PAN, Pracownia Pozyskiwania Surowców Mineralnych, Kraków; e-mail: kopacz@min-pan.krakow.pl 
Tabela 1. Gospodarka odpadami wydobywczymi w sektorze węgla kamiennego w Polsce na tle wydobycia węgla w latach 2007-2013

Table 1. Waste rock management in Polish coal mining industry against the coal production in 2007-2013

\begin{tabular}{|c|c|c|c|c|c|c|c|c|c|}
\hline Lp. & Wyszczególnienie & J.m. & 2007 & 2008 & 2009 & 2010 & 2011 & 2012 & 2013 \\
\hline 1. & Wytwarzanie skały płonnej ogółem & [tys. Mg] & 36626,5 & 32567,7 & 30652,5 & 34382,0 & 33165,0 & 34153,9 & 35138,2 \\
\hline 2. & $\begin{array}{l}\text { Składowanie skały płonnej na } \\
\text { powierzchni }\end{array}$ & [tys. Mg] & 529,4 & 670,1 & 2344,5 & 1474,0 & 5259,5 & 4722,4 & 6083,9 \\
\hline 3. & $\begin{array}{l}\text { Wykorzystanie skały płonnej na } \\
\text { powierzchni }\end{array}$ & [tys. Mg] & 34922,9 & 31019,2 & 27627,6 & 32209,9 & 27326,3 & 29285,3 & 28550,3 \\
\hline 4. & $\begin{array}{l}\text { Zagospodarowanie skały płonnej na } \\
\text { dole }\end{array}$ & [tys. Mg] & 1174,2 & 878,4 & 680,4 & 698,1 & 579,2 & 479,7 & 467,6 \\
\hline 5. & Wydobycie węgla & [tys. Mg] & 87210,3 & 83647,4 & 77449,2 & 76153,8 & 75667,8 & 79234,2 & 76466,3 \\
\hline S1. & $\begin{array}{l}\text { Udział skały płonnej w wydobyciu } \\
\text { urobku brutto }(1) /(1+5)\end{array}$ & {$[\%]$} & $29,6 \%$ & $28,0 \%$ & $28,4 \%$ & $31,1 \%$ & $30,5 \%$ & $30,1 \%$ & $31,5 \%$ \\
\hline S2. & $\begin{array}{l}\text { Wspólczynnik uzysku węgla netto: } \\
(5) /(1+5)\end{array}$ & {$[\%]$} & $70,4 \%$ & $72,0 \%$ & $71,6 \%$ & $68,9 \%$ & $69,5 \%$ & $69,9 \%$ & $68,5 \%$ \\
\hline s3. & $\begin{array}{l}\text { Udział skały płonnej składowanej na } \\
\text { powierzchni: }(2) /(1)\end{array}$ & {$[\%]$} & $1,4 \%$ & $2,1 \%$ & $7,6 \%$ & $4,3 \%$ & $15,9 \%$ & $13,8 \%$ & $17,3 \%$ \\
\hline s4. & $\begin{array}{l}\text { Udział skały płonnej wykorzystywanej } \\
\text { gospodarczo: (3)/(1) }\end{array}$ & {$[\%]$} & $95,3 \%$ & $95,2 \%$ & $90,1 \%$ & $93,7 \%$ & $82,4 \%$ & $85,7 \%$ & $81,3 \%$ \\
\hline s5. & $\begin{array}{l}\text { Udzial skały płonnej } \\
\text { zagospodarowywanej na dole: (4)/(1) }\end{array}$ & {$[\%]$} & $3,2 \%$ & $2,7 \%$ & $2,2 \%$ & $2,0 \%$ & $1,7 \%$ & $1,4 \%$ & $1,3 \%$ \\
\hline
\end{tabular}

Źródło: opracowanie własne na bazie danych z ARP

- w dłuższej perspektywie, tj. w latach 2003-2013, ujawnia się rosnący udział ilości wytwarzanej skały płonnej w łącznym wydobyciu kopalń (zmiana o 5,5 pkt. proc., z poziomu 26,0\% w roku 2003 do 31,5\% w roku 2013 r.) - rysunek 1.

Przez współczynnik uzysku węgla netto (WUWN) w niniejszej pracy rozumie się stosunek ilości wydobytego węgla do masy urobku węglowego (brutto). Odpowiednio wskaźnik zanieczyszczenia węgla stanowi iloraz ilości skały płonnej i wydobycia brutto. Oba wskaźniki wyraża się w procentach.

Wysoki udział skały płonnej w wydobyciu urobku węglowego oraz systematycznie pogarszająca się relacja wydobycia węgla do ilości powstających odpadów może rodzić liczne pytania. Stają się one istotne w przypadku podejmowania decyzji o budowie nowych kopalń, czy też określaniu strategii wobec obecnie istniejących, w szczególności tych bę- 


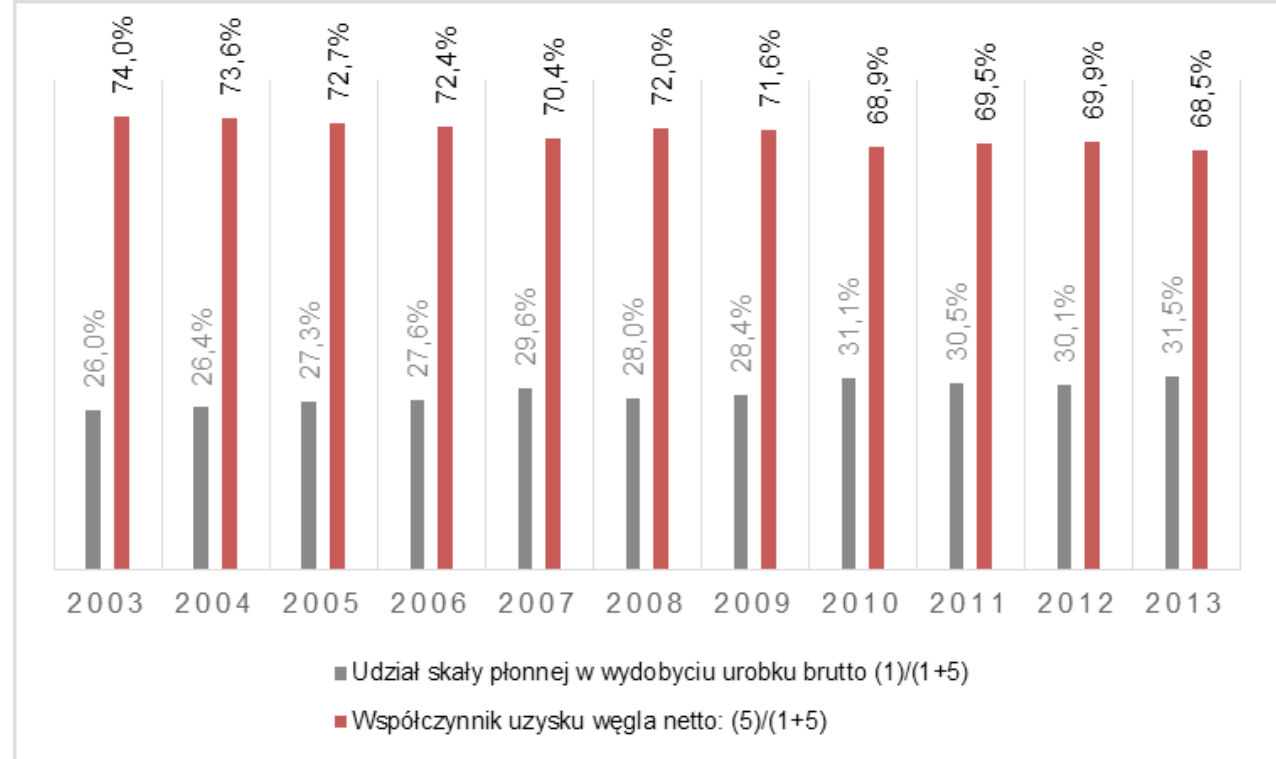

Rys. 1. Zmiany współczynnika uzysku węgla netto oraz ilości skały płonnej w sektorze węgla kamiennego w Polsce w latach 2003-2013

Źródło: opracowanie własne na bazie danych z ARP

Fig. 1. The variations of coal yield and waste rock in the Polish hard coal industry in 2003-2013

dących w trudnej sytuacji gospodarczej. Najważniejsze z tych pytań, stanowiących zasadniczo pytania o cel, zakres i istotę prowadzonych $\mathrm{w}$ niniejszej publikacji analiz zestawiono poniżej:

1. Jakie są łączne koszty działalności operacyjnej w nowo projektowanej kopalni, będące pochodną eksploatacji węgla oraz wydobywania skały płonnej?

2. Jaki jest wpływ ilości (i kosztów) skały płonnej na kluczowe wyniki ekonomiczno-finansowe modelowej kopalni w długiej perspektywie czasu?

3. Jakie są koszty urabiania skały płonnej pochodzącej z różnych jej źródeł?

4. Czy w rzeczywistości tyle samo kosztuje skała płonna pochodząca z opadu stropu, przerostów i przybierki spągu?

Na tym tle zarysowuje się teza publikacji, która streszcza się w sformułowaniu, iż urabianie skały płonnej w przodkach chodnikowych i ścianach istotnie wpływa na zyskowność prowadzonego wydobycia oraz łączny poziom kosztów w kopalniach, a tym samym - wyniki finansowe poszczególnych podmiotów górniczych.

Analizując literaturę przedmiotu należy stwierdzić, że zainteresowanie oceną kosztów urabiania skały płonnej na dole kopalń węgla kamiennego w warunkach pogarszających się parametrów geologiczno-górniczych złóż nie znajduje dużego zainteresowania.

Problematyką szeroko rozumianej gospodarki skałą płonną i określaniem wartości mułów węglowych deponowanych w osadnikach zajmował się prof. Blaschke (Blaschke 2005). 
Odniesienie do tematyki analizy kosztów i korzyści zagospodarowania odpadów z górnictwa węgla kamiennego i brunatnego można znaleźć w publikacji J. Kulczyckiej (Kulczycka $i$ in. 2014). Zagadnienia tam poruszane dotyczą kwestii ekonomicznych, społecznych i ekologicznych, wynikających z wykorzystania kopalin towarzyszących i odpadów wydobywczych.

Analizą opłacalności różnych sposobów utylizacji skały płonnej w kopalniach węgla kamiennego zajmowali się m.in. R. Frączek (Frączek 1992) oraz J. Włoszek (Włoszek 2002). W swoich pracach wskazują oni na możliwości szacowania kosztów utylizacji kamienia i odpadów drobnofrakcyjnych w wyrobiskach chodnikowych i przodkach ścianowych.

Ewidencją, oceną i klasyfikacją kosztów operacyjnych zakładów górniczych, najczęściej w ujęciu projektowym, zajmowali się m.in. M. Turek (Turek 2013), M. Sierpińska i A. Kustra (Kustra i Sierpińska 2013), A. Karbownik (Karbownik 2007), czy K. Czopek (Czopek 2002). Zagadnienia poruszane w publikacjach ww. autorów dotyczyły zasadniczo ewidencji i rozliczania kosztów zidentyfikowanych projektów, właściwego zarządzania kosztami w cyklu życia projektu geologiczno-górniczego, czy wydzielonych pól eksploatacyjnych.

\section{Ewidencja kosztów skały płonnej w kopalniach węgla kamiennego}

W zakładach wydobywczych rejestr kosztów prowadzony jest jednocześnie w kilku układach ewidencji.

Podstawowym przekrojem kosztów jest układ rodzajowy, obejmujący ogół kosztów prostych poniesionych w okresie sprawozdawczym. Równolegle funkcjonuje także układ kalkulacyjny, w ramach którego gromadzi się koszty produkcji według nośników, w przekroju poszczególnych wyrobów. W układzie funkcjonalnym prowadzi się z kolei ewidencję i wykazuje koszty zakupu, działalności podstawowej i pomocniczej, koszty ogólnego zarządu oraz koszty sprzedaży (Jajuga i Jajuga 2000).

W układzie według miejsc powstawania kosztów ewidencjonuje się koszty podstawowych obiektów dekretacji, w miejscach ich powstawania przypisanych do fizycznej lokalizacji, tudzież określonego procesu lub środka trwałego (Damodaran 2007). W kopalniach węgla kamiennego układ ten tworzy tzw. Oddziałowy Rachunek Kosztów (ORK).

Mimo, że te cztery różne układy (przekroje) ewidencji spełniają podstawowe potrzeby kopalń, to pomiędzy celami zarządczymi - operacyjnymi a zdarzeniami finansowo-księgowymi istnieją rozbieżności.

W obszar ten włącza się zagadnienie ewidencji skały płonnej, która nie stanowi obiektu podlegającego szczegółowej kontroli kosztów.

W dotychczasowej ewidencji kosztów w ramach stanowisk kosztów Oddziałowego Rachunku Kosztów w poszczególnych kopalniach nie widnieją osobno wydzielone obiekty dekretacji zorientowane na precyzyjny monitoring kosztów skały płonnej w przekroju źródeł jej pochodzenia. Dotyczy to zarówno kosztów urabiania skały płonnej w przodkach ściano- 
wych, czy chodnikowych, jak i w ramach samych ścian - z tytułu opadu stropu, przybierki spągu, czy też ze względu na przyczyny naturalne (obecność przerostów).

Nieco lepiej prowadzony jest monitoring kosztów skały płonnej już na powierzchni, w ramach procesów unieszkodliwiania odpadów na składowisku, czy też ich wywozu poza teren kopalni. Koszty gospodarki skałą płonną na powierzchni stanowią jednak niewielki odsetek całości kosztów operacyjnych kopalń węgla kamiennego.

Powyższe obserwacje prowadzą do wniosku, że przybliżenie faktycznych kosztów urabiania skały płonnej dla celów zarządczych może być przeprowadzone jedynie poprzez rozbicie zagregowanych kosztów operacyjnych w miejscach ich powstawania i identyfikację kosztów związanych tylko z urabianiem kamienia.

Przyczyn tego stanu rzeczy należy upatrywać niewątpliwie w specyfice procesu eksploatacyjnego, któremu nieodłącznie towarzyszy skała płonna. Zakłady górnicze dążą do maksymalizacji rezultatów ekonomicznych, co stanowi - skądinąd - istotę ich działalności. Znajduje to również wyraz w specyfice prowadzonej ewidencji kosztów produkcji.

Próba identyfikacji kosztów powstającej skały płonnej „u źródła” oraz oceny jej wpływu na zyskowność procesu udostępnienia, zagospodarowania i wydobycia węgla w „nowej kopalni” stała się kluczowym elementem prowadzonej analizy.

\section{Koncepcja analizy}

Pomiar wpływu kosztów powstającej na dole kopalń skały płonnej na kształtowanie się parametrów i wyników oceny efektywności ekonomicznej hipotetycznej kopalni węgla kamiennego lokowanej na nowym złożu przeprowadzono w trzech etapach. Złoże to oznaczono umownie symbolem „X”. Udostępnienie, zagospodarowanie i eksploatację zasobów złoża „X” traktowano jako nowe przedsięwzięcie inwestycyjne w okresie do całkowitego sczerpania zasobów operatywnych węgla.

W pierwszym etapie skonstruowano arkusz kalkulacyjny - model dyskontowy, za pomocą którego określano wartość hipotetycznej kopalni węgla kamiennego. Oceny efektywności ekonomicznej projektu inwestycyjnego dokonano przy użyciu trzech klasycznych metod (mierników):

- wartości zaktualizowanej netto (NPV, net present value),

- wewnętrznej stopy zwrotu (IRR, internal rate of return),

- wskaźnika wartości zaktualizowanej netto (NPVR, net present value ratio).

Wpływ zmiennej ilości skały płonnej odzwierciedlono także prezentując kluczowe mierniki działalności operacyjnej (EBIT - ernings before intersts and taxes; odpowiednik zysku netto) oraz w połączeniu $\mathrm{z}$ działalnością inwestycyjną i finansową - w postaci łącznych przepływów pieniężnych netto. Koncepcja modelu obejmowała ponadto projekcję nakładów, kosztów, kalkulację potencjalnych przychodów, jak i dobór pozostałych zmiennych ekonomiczno-finansowych, niezbędnych dla oszacowania efektywności ekonomicznej hipotetycznej kopalni. 
W drugim etapie dokonywano rekalkulacji przyjętych kosztów wydobycia węgla na koszty wydobycia urobku węglowego (brutto) przy zmiennym udziale skały płonnej.

W szczególności dokonywano przeliczenia jednostkowych gotówkowych kosztów operacyjnych (koszty operacyjne pomniejszone o amortyzację, bez innych korekt) biorąc pod uwagę:

- miejsca powstawania kosztów (wyrobisko ścianowe lub chodnik),

- rodzaj eksploatowanej kopaliny (węgiel bądź kamień).

Przyjęto ponadto, że w wyrobiskach ścianowych potencjalnymi źródłami (miejscami) powstawania skały płonnej będą:

- przybierki stropu i spągu,

przerosty,

- opad stropu.

W przypadku wyrobisk chodnikowych dokonywano rozróżnienia źródeł i kosztów skały płonnej, biorąc pod uwagę:

- przekroje wyrobisk chodnikowych,

- udziały (ilości) węgla i kamienia.

W trzecim etapie do modelu wyceny wprowadzono procedury symulacyjne, umożliwiające testowanie wartości analizowanych parametrów oraz kalkulację kosztów urabiania skały płonnej w funkcji zmieniającego się poziomu WUWN.

Kluczowe znaczenie w symulacji posiadało jednak dynamiczne szacowanie ilości skały płonnej w poszczególnych latach przy znacznej charakterystyce jakościowej złoża oraz doświadczeniach związanych z eksploatacją w złożu macierzystym (przyległym).

Należy podkreślić, iż symulacji przyświecało założenie, że stan zasobów operatywnych w złożu będzie taki sam, a zmieniać się będzie ilość wytwarzanej skały płonnej.

W symulacji założono także brak technicznych ograniczeń infrastruktury hipotetycznej kopalni (brak tzw. wąskich gardeł) uniemożliwiających wydobycie zakładanej - w skrajnym przypadku (WUWN 50,0\%) równej wydobyciu węgla - ilości skały płonnej.

Określenie ilości skały płonnej, w podziale na kierunki i miejsca jej powstawania, stanowiło podstawę wykonywanego rachunku kosztów.

Ostatecznie, symulację kosztów wydobycia, zmian wartości projektu oraz wybranych parametrów technicznych i ekonomicznych hipotetycznej kopalni przedstawiono jako funkcję zmiennej ilości skały płonnej. Badania symulacyjne przeprowadzono dla wartości WUWN zmieniających się w zakresie od 50,0 do 100,0\% w założonym horyzoncie analizy. Zachowano także zgodność z pierwotną strukturą przepływów pieniężnych, co miało znaczenie dla oceny przyjętych miar wartości i ryzyka na poziomie zdyskontowanym.

\subsection{Kluczowe założenia}

Poniżej scharakteryzowano kluczowe założenia służące budowie modelu symulacyjnego, za pomocą którego dokonano oceny wpływu zmiennej ilości skały płonnej na rezultaty oceny projektu i wybrane mierniki (wskaźniki) ekonomiczno-finansowe. 


\subsubsection{Zasoby węgla, model kopalni i harmonogram wydobycia}

Zasoby operatywne węgla do wydobycia ze złoża „X” oszacowano na około 230,3 mln Mg (zasoby węgla w wyrobiskach ścianowych i chodnikowych łącznie).

Analizując parametry jakościowe złoża przestawione na rysunku 2 można zauważyć, że wraz z postępem eksploatacji w czasie rośnie kaloryczność węgla, zwiększa się miąższość pokładów, obniża się zawartość popiołu oraz siarki.
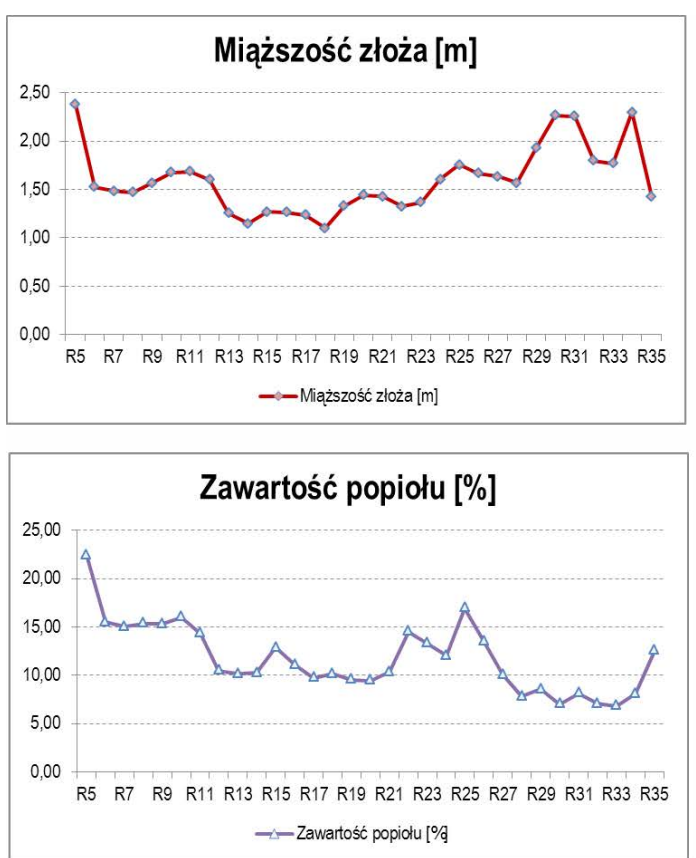
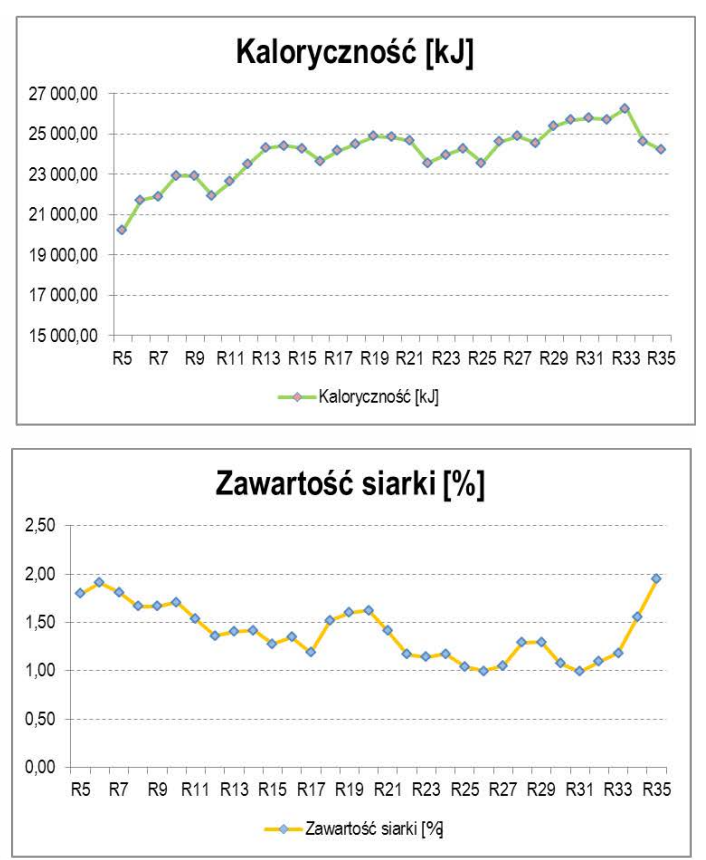

Rys. 2. Charakterystyka parametrów jakościowych złoża „X”

Fig. 2. The characteristics of quality parameters of the deposit "X”

Przyjęto, że docelowa zdolność produkcyjna będzie wynosić 9,0 $\mathrm{mln}$ Mg węgla handlowego rocznie. Na tej podstawie okres istnienia kopalni oszacowano na 35 lat.

Optymalizacja haromonogramu wydobycia nie była przedmiotem analiz.

Harmonogram eksploatacji złoża „X” przedstawiono na rysunku 3.

W analizowanym projekcie łączna ilość skały płonnej została oszacowana na około 78,6 mIn Mg (przy empirycznie ustalonym, średnim w okresie kolejnych 35 lat realizacji projektu, uzysku węgla netto na poziomie $74,6 \%$ ).

Bilans skały płonnej w kolejnych okresach analizy na tle zmienności WUWN przestawiono na rysunku 4. 


\section{Produkcja węgla handlowego [Mg]}

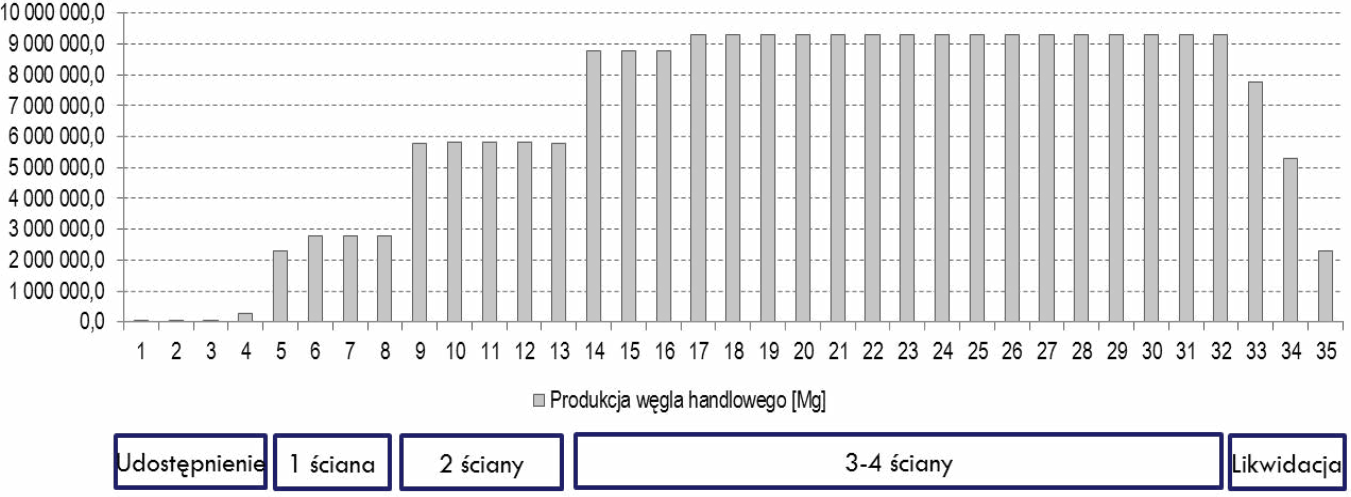

Rys. 3. Harmonogram eksploatacji zasobów złoża „X”

Fig 3. The exploitation schedule of the deposit " $\mathrm{X}$ "

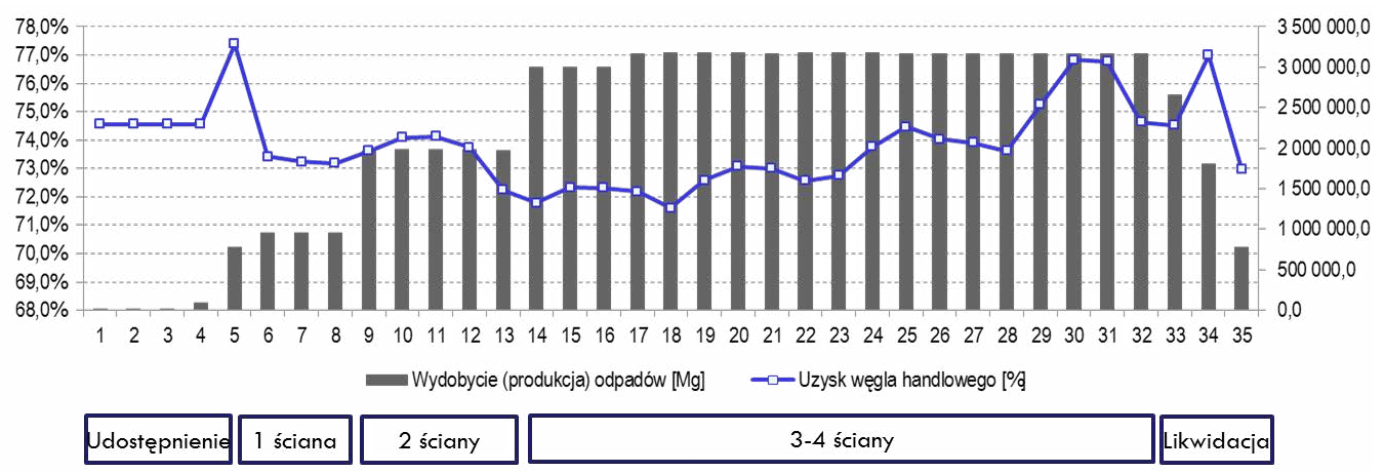

Rys. 4. Bilans skały płonnej powstającej ze złoża „X”; scenariusz bazowy

Fig. 4. The balance of waste rock as a result of exploitation of the deposit "X"; baseline scenario

Z kolei charakterystykę robót (wyrobisk) chodnikowych oraz założenia służące oszacowaniu ilości powstającej skały płonnej i wydobywanego z nich węgla przedstawia tabela 2 . 
Tabela 2. Kalkulacja ilości skały płonnej i wydobycia węgla z wyrobisk chodnikowych złoża „X”

Table 2. Estimation of waste rock and coal production from drifts of the deposit " $\mathrm{X}$ ".

\begin{tabular}{|c|c|c|}
\hline Wyszczególnienie & J.m. & Wartość \\
\hline Liczba wyrobisk udostępniających & {$[\mathrm{m}]$} & 107400,0 \\
\hline - w strukturze kamiennej & {$[\%]$} & $95,9 \%$ \\
\hline - w strukturze mieszanej & {$[\%]$} & $4,1 \%$ \\
\hline Średnia liczba wyrobisk udostępniających & {$[\mathrm{m} / \mathrm{rok}]$} & 3580,0 \\
\hline - w strukturze kamiennej & {$[\mathrm{m} / \mathrm{rok}]$} & 3433,0 \\
\hline - w strukturze mieszanej & {$[\mathrm{m} / \mathrm{rok}]$} & 147,0 \\
\hline Liczba ścian & [szt.] & 123,0 \\
\hline Liczba wyrobisk konturujących & {$[\mathrm{m}]$} & 5300,0 \\
\hline - średni wybieg & {$[\mathrm{m}]$} & 2500,0 \\
\hline - średnia długość ściany & {$[\mathrm{m}]$} & 300,0 \\
\hline - średnia miąższość pokładu & {$[\mathrm{m}]$} & 1,75 \\
\hline Liczba lat z wydobyciem & [lata] & 30,0 \\
\hline Ciężar objętościowy skały płonnej & {$\left[\mathrm{g} / \mathrm{cm}^{3}\right]$} & 2,50 \\
\hline Ciężar objętościowy węgla & {$\left[\mathrm{g} / \mathrm{cm}^{3}\right]$} & 1,38 \\
\hline Ważony ciężar objętościowy urobku & {$\left[\mathrm{g} / \mathrm{cm}^{3}\right]$} & 2,45 \\
\hline Liczba wyrobisk przygotowawczych & {$[\mathrm{m}]$} & 651900,0 \\
\hline Średnia ilość wyrobisk przygotowawczych & {$[\mathrm{m} / \mathrm{rok}]$} & 21730,0 \\
\hline Średnia ilość skały płonnej (wyr. udostępniające) & {$[\mathrm{Mg} / \mathrm{rok}]$} & 248953,2 \\
\hline Średnia ilość skały płonnej (wyr. przygotowawcze) & {$[\mathrm{Mg} / \mathrm{rok}]$} & 855873,0 \\
\hline Średnia całkowita ilość skały płonnej (wyr. chodnikowe) & {$[\mathrm{Mg} / \mathrm{rok}]$} & 1104826,2 \\
\hline Średnie wydobycie węgla netto (wyr. udostępniające) & {$[\mathrm{Mg} / \mathrm{rok}]$} & 14327,2 \\
\hline Średnie wydobycie węgla netto (wyr. przygotowawcze) & {$[\mathrm{Mg} / \mathrm{rok}]$} & 268387,2 \\
\hline Średnie całkowite wydobycie węgla netto (wyr. chodnikowe) & {$[\mathrm{Mg} / \mathrm{rok}]$} & 282714,4 \\
\hline
\end{tabular}

\subsubsection{Nakłady inwestycyjne i koszty operacyjne}

Przyjęto, że analizowany projekt będzie funkcjonował jako odrębne przedsięwzięcie inwestycyjne, w części korzystając z infrastruktury kopalni macierzystej, którego łączne nakłady inwestycyjne w całym okresie istnienia skalkulowano na około 7,70 mld zł. Wyszczególnienie nakładów w podstawowych grupach prezentuje tabela 3. 
Tabela 3. Kalkulacja nakładów inwestycyjnych hipotetycznej kopalni węgla kamiennego „X”

Table 3. Calculation of the capital expenditure for hypothetical coal mine " $\mathrm{X}$ "

\begin{tabular}{|c|l|c|}
\hline Lp. & \multicolumn{1}{|c|}{ Wyszczególnienie/kierunki inwestycyjne } & [tys. zt] \\
\hline 1. & Inf. geologiczna i dokumentacja projektowa & 63600,0 \\
\hline 2. & Budownictwo podziemne poziome & 1700000,0 \\
\hline 3. & Drążenie i budowa szybu & 619000,0 \\
\hline 4. & Infrastruktura powierzchniowa i dołowa & 227100,0 \\
\hline 5. & Budowa zakładu przeróbczego & 200000,0 \\
\hline 6. & Zakupy kompleksów ścianowych i maszyn urabiających & 1792044,0 \\
\hline 7. & Pozostałe zakupy & 661964,7 \\
\hline 8. & Pozostałe nakłady & 2238800,0 \\
\hline 9. & Rezerwa (10\%) & 195000,0 \\
\hline
\end{tabular}

Kalkulacja kosztów działalności operacyjnej i gospodarki skałą płonną

Koszty operacyjne gotówkowe w scenariuszu podstawowym przyjęto na poziomie $180,0 \mathrm{zz} / \mathrm{Mg}$ węgla handlowego (średnie koszty operacyjne wraz z amortyzacją w ujęciu jednostkowym skalkulowano na 210,1 zł/Mg w.h.). Odpowiada to jednostkowym gotówkowym kosztom wydobycia urobku węglowego na poziomie 134,2 zł/Mg (wydobycie netto 230,3 mln Mg węgla; wydobycie brutto 308,9 mln Mg).

Dla zróżnicowania kosztów wydobycia urobku węglowego w nowym złożu posłużono się w szczególności ewidencją kosztów w miejscach ich powstawania na podstawie danych pobranych z kopalni macierzystej.

W pierwszym, przeprowadzono dekompozycję całości kosztów operacyjnych kopalni macierzystej w układzie centrów odpowiedzialności za koszty ( 9 centrów kosztów; tab. 4), zgodnie z przyjętymi zasadami Oddziałowego Rachunku Kosztów. Przyjęto, że na koszty wydobycia składać się będą koszty, odpowiednio:

- w wyrobiskach ścianowych:

- dla urobku pochodzącego z przybierek oraz przerostów w pokładzie - wszystkich centrów kosztów, za wyjątkiem centrum przygotowawczego,

- dla skały płonnej pochodzącej z opadu stropu - centrum transportowego, szybowego, przeróbki mechanicznej (urobek ten nie jest wynikiem celowego urabiania);

- w wyrobiskach chodnikowych (tj. robót udostępniających i przygotowawczych):

- wszystkich centrów, za wyjątkiem centrum wydobywczego.

Wyniki wymienionych prac przedstawiono w tabeli 4 i 5.

Na rysunku 5 zilustrowano proces szacowania kosztów wydobycia węgla i skały płonnej w ujęciu jednostkowym. Finalna struktura kosztu jednostkowego, uwzględniająca zarówno 
Tabela 4. Struktura kosztów gotówkowych wydobycia węgla (skały płonnej) w układzie ośrodków odpowiedzialności za koszty (centra kosztów)

Table 4. Cash cost structure of coal production and waste rock broken down into cost centers

\begin{tabular}{|c|c|c|c|c|c|}
\hline \multicolumn{4}{|c|}{ Koszty gotówkowe [\%] alokowane na } & \multirow{2}{*}{\multicolumn{2}{|c|}{$\begin{array}{l}\text { Struktura (I) kosztów operacyjnych } \\
\text { dla wydobycia skały }\end{array}$}} \\
\hline \multicolumn{2}{|c|}{ centrum kosztów } & \multirow{2}{*}{$\begin{array}{c}\text { ściany } \\
16,9\end{array}$} & \multirow{2}{*}{$\begin{array}{c}\text { chodniki } \\
0,0\end{array}$} & & \\
\hline Wydobywcze & 16,9 & & & Wyrobiska ścianowe & $64,0 \%$ \\
\hline Przygotowawcze & 28,4 & 0,0 & 28,4 & - przebierki i przerosty & $64,0 \%$ \\
\hline Elektryczne & 11,7 & 10,1 & 1,6 & opad stropu & $21,8 \%$ \\
\hline Mechaniczne & 13,0 & 11,2 & 1,8 & Wyrobiska chodnikowe & $36,0 \%$ \\
\hline Szybowe & 8,2 & 7,1 & 1,1 & & \\
\hline Pomocnicze & 1,1 & 1,0 & 0,2 & & \\
\hline Transportowe & 9,2 & 7,9 & 1,3 & & \\
\hline Wentylacji & 3,4 & 3,0 & 0,5 & & \\
\hline Przeróbki mech. & 8,0 & 6,9 & 1,1 & & \\
\hline Suma końcowa & 100,0 & 64,9 & 36,0 & & \\
\hline
\end{tabular}

lokalizację źródeł skały płonnej (lub węgla) oraz dodatkowe koszty związane z urabianiem kamienia stanowi iloczyn struktury kosztów według ośrodków odpowiedzialności za koszty i struktury kosztów wydobycia szacowanych na bazie układu rodzajowego kosztów kopalni macierzystej.

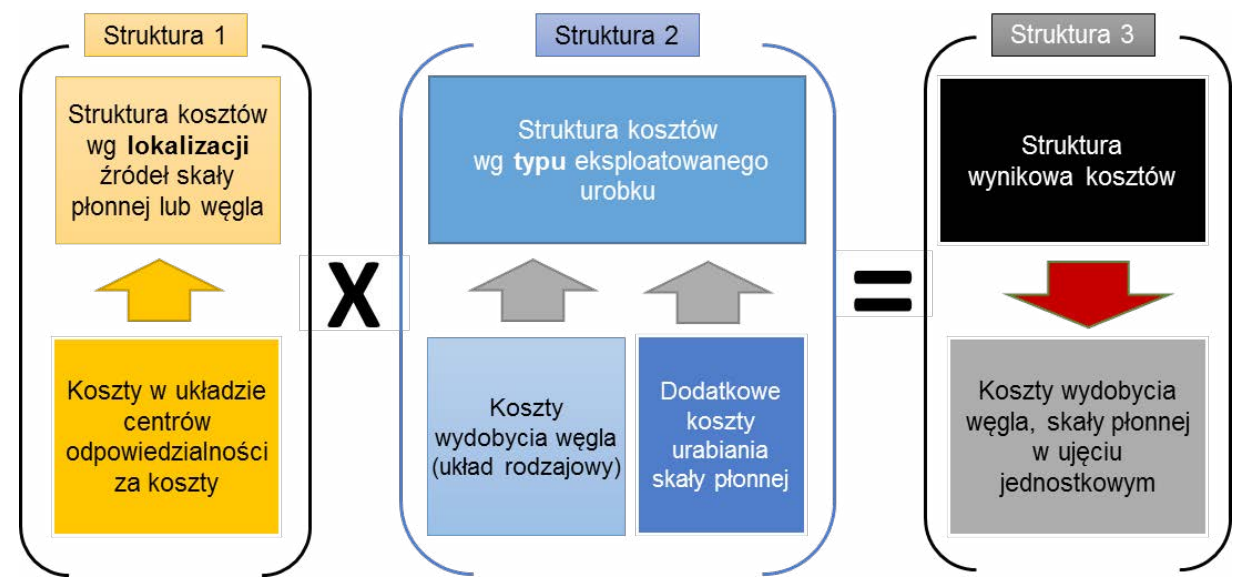

Rys. 5. Ilustracja graficzna procesu szacowania gotówkowych kosztów wydobycia węgla i skały płonnej w modelu ekonomicznym

Źródło: opracowanie własne

Fig. 5. Graphic illustration of the process of estimating the cost of coal production and waste rock in the economic model 
Można wymienić kilka argumentów przemawiających za korektą kosztów wydobycia ze względu na rosnący udział skały płonnej:

- urabianie skały płonnej wpływa negatywnie na stopień wykorzystania posiadanych aktywów produkcyjnych (mniejsze postępy, krótszy efektywny czas pracy: domniemany wyższy poziom postojów nieplanowanych, niższa produktywność załogi), co może mieć konsekwencje:

- we wzroście KOSZTÓW BEZPOŚREDNICH: zużycia materiałów eksploatacyjnych, części zamiennych maszyn urabiających, remontów, serwisów zewnętrznych, czy też robocizny,

- we wzroście POZOSTAŁYCH KOSZTÓW, w szczególności kosztów procesów towarzyszących (wentylacja i klimatyzacja, odwadnianie, profilaktyka i procesy BHP, utrzymanie wyrobisk, dozór dołowy), transportu poziomego, pionowego i przeróbki;

- dla niskich i bardzo niskich poziomów współczynnika uzysku węgla netto wzrost poziomu zanieczyszczenia urobku będzie skutkował dalszym obniżeniem efektywności procesu wydobywczego i wymusi określone konsekwencje organizacyjne:

- wprowadzenie dodatkowych oddziałów produkcyjnych,

- zmiana systemu organizacji pracy (dodatkowe zmiany robocze, wydłużenie tygodnia pracy)

Aby zatem przybliżyć możliwy zakres zmian kosztów, w analizie przyjęto założenie, iż eksploatacja ścian z dużym udziałem kamienia oraz chodników drążonych mechanicznie w strukturze mieszanej i kamiennej będzie - umownie (na bazie szacunku eksperckiego) - o 20,0\% droższa w stosunku do wartości charakterystycznych dla urabiania węgla (tab. 5; struktura 2; kolumna nr 5). Dotyczy to kosztów bezpośrednich wydobycia w przodkach.

$\mathrm{Na}$ tej podstawie koszty przypisane uprzednio do miejsc ich powstawania i w różnych przekrojach ewidencji posłużyły do przybliżenia wartości jednostkowych bezpośrednich kosztów wydobycia węgla i skały płonnej w ścianach i przodkach chodnikowych (tab. 5, kolumny 9 i 10).

Uwzględniając pozostałe argumenty, przemawiające za zwiększaniem kosztów urabiania skały płonnej (przy uzysku węgla różnym niż bazowy: 74,6\%) do modelu ekonomicznego (w kosztach) wprowadzono dodatkowe założenia.

W symulacji, dla wartości współczynnika uzysku węgla netto:

- w przedziale $(60,0-75,0 \%)$, z tytułu pogarszających się warunków geologicznych i górniczych założono, że nastąpi proporcjonalny wzrost pozostałych kosztów wydobycia od 0,0 do $5,0 \%$ (wyższe koszty dla niższego uzysku węgla),

- poniżej poziomu $60,0 \%$ przyjęto, iż w kopalni wystąpi konieczność wprowadzenia kolejnego oddziału wydobywczego (pojawią się nieplanowane, dodatkowe nakłady i koszty związane z uruchomieniem dodatkowych zdolności produkcyjnych i pozostałych procesów wsparcia). W związku z tym, założono skokowy wzrost średnich rocznych kosztów operacyjnych (o $15,0 \%$ ) i proporcjonalny wzrost na- 
Tabela 5. Jednostkowe gotówkowe koszty wydobycia węgla i skały płonnej w przodkach wydobywczych

Table 5. Unit cash costs of coal production and waste rock exploitation form longwall faces and headings

\begin{tabular}{|c|c|c|c|c|c|c|c|c|c|}
\hline 1 & 2 & 3 & 4 & 5 & 6 & 7 & 8 & 9 & 10 \\
\hline \multirow[b]{2}{*}{ Wyszczególnienie } & & & & & & \multirow{2}{*}{\multicolumn{2}{|c|}{$\begin{array}{l}3 \text { Struktura } \\
\text { (wynikowa) }\end{array}$}} & \multicolumn{2}{|c|}{ Koszty } \\
\hline & \multicolumn{2}{|c|}{ Struktura 1} & \multicolumn{3}{|c|}{ Struktura 2} & & & $\begin{array}{c}{[\mathrm{zl} / \mathrm{Mg}]} \\
\text { urobku } \\
\text { brutto }\end{array}$ & $\begin{array}{c}\text { [zł/Mg] } \\
\text { (węgla/ } \\
\text { skały } \\
\text { płonnej) }\end{array}$ \\
\hline $\begin{array}{l}\text { Wyrobiska ścianowe } \\
\text { (węgiel) }\end{array}$ & $64,0 \%$ & $28,8 \%$ & $100,0 \%$ & & $21,7 \%$ & $4,7 \%$ & $44,9 \%$ & 59,3 & 82,9 \\
\hline $\begin{array}{l}\text { Wyrobiska ścianowe } \\
\text { (skała płonna) }\end{array}$ & $64,0 \%$ & & & & & & & & \\
\hline $\begin{array}{l}\text { przebierki } \\
\text { i przerosty }\end{array}$ & $64,0 \%$ & $28,8 \%$ & $120,0 \%$ & $(+20 \%)$ & $26,1 \%$ & $1,9 \%$ & $18,4 \%$ & 24,3 & 199,9 \\
\hline $\begin{array}{l}\text { przebierki } \\
\text { i przerosty }\end{array}$ & $21,8 \%$ & $9,8 \%$ & $20,0 \%$ & & $4,3 \%$ & $0,1 \%$ & $1,0 \%$ & 1,4 & 39,8 \\
\hline $\begin{array}{l}\text { Wyrobiska chodnikowe } \\
\text { (węgiel) }\end{array}$ & $36,0 \%$ & $16,2 \%$ & $100,0 \%$ & & $21,7 \%$ & $2,6 \%$ & $25,3 \%$ & 33,4 & 1135,3 \\
\hline $\begin{array}{l}\text { Wyrobiska chodnikowe } \\
\text { (skała płonna) }\end{array}$ & $36,0 \%$ & $16,2 \%$ & $120,0 \%$ & $(+20 \%)$ & $26,1 \%$ & $1,1 \%$ & $10,4 \%$ & 13,7 & 148,2 \\
\hline
\end{tabular}

kładów inwestycyjnych (rzędu 10,0 zł/Mg urobku na zakup dodatkowego parku maszynowego),

- wyższych niż 76,0\%, nastąpi proporcjonalny spadek pozostałych kosztów operacyjnych; przy skrajnie wysokim WUWN (99,0\%) odpowiednio do poziomu 80,0\% wartości bazowych kosztów wydobycia. W tym przypadku wykluczono realną możliwość likwidacji zbędnych mocy wydobywczych, co miałoby przełożenie np. na oszczędności z tytułu likwidacji części majątku produkcyjnego i kosztów osobowych.

Koszty całkowite szacowano ostatecznie jako sumę kosztów wydobycia węgla i skały płonnej. Stanowiły one z kolei iloczyn kosztów jednostkowych i zakładanego wydobycia w przekroju analizowanych miejsc i źródeł ich powstawania.

\subsubsection{Kalkulacja pozostałych parametrów modelu ekonomiczno-finansowego}

Cena sprzedaży węgla handlowego

Średnia cena sprzedaży węgla handlowego była kalkulowana poprzez korektę ceny bazowej (230,0 zł/Mg węgla wskaźnikowego) w poszczególnych okresach analizy ze względu na kaloryczność, zawartość popiołu i siarki faktycznie wydobywanego węgla. 
Posłużono się w tym celu następującą formułą (Grudziński 2009):

$$
P_{r z}=P_{b} \cdot \frac{Q_{r z}}{Q_{b}}-w_{s} \cdot\left(S_{r z}-S_{b}\right)-w_{a} \cdot\left(A_{r z}-A_{b}\right)
$$

$\stackrel{\leftrightarrow}{\rightarrow} P_{r z}-$ kalkulowana cena sprzedaży $[\mathrm{z} / \mathrm{Mg}]$,

$P_{b} \quad-$ cena referencyjna $[\mathrm{zl} / \mathrm{Mg}]$,

$Q_{r z} \quad-$ kaloryczność węgla w złożu,

$Q_{b} \quad-$ kaloryczność węgla referencyjnego $(21 \mathrm{MJ} / \mathrm{kg})$,

$S_{r z} \quad-$ zawartość siarki w węglu, w złożu,

$S_{b} \quad-$ zawartość siarki w węglu referencyjnym (1,13\%)

$A_{r z} \quad-$ zawartość popiołu w węglu, w złożu,

$A_{b} \quad-$ zawartość popiołu w węglu referencyjnym $(22,0 \%)$,

$w_{s}, w_{a}-$ współczynniki korygujące, uwzględniające odpowiednie koszty ekologiczne spalania i składowania odpadów powstałych z $1 \mathrm{Mg}$ węgla $\left(w_{s}=11,0 ; w_{a}=0,4\right)$ (Grudziński 2009).

Dane o parametrach jakościowych węgla referencyjnego ustalono na podstawie średnich z LW „Bogdanka” SA, w relacji do ceny bazowej tego węgla.

Stopa dyskontowa

Przy doborze stopy dyskonta dostosowanej do ryzyka (RADR, risk adjusted discount rate) dla analizowanego złoża wzięto pod uwagę:

- błędy oszacowania średnich paramentów jakościowych złoża (miąższości, kaloryczności, popiołu, siarki),

Tabela 6. Stopa RADR dla złoża „X” w kolejnych rocznych okresach obliczeniowych

Table 6. Risk adjusted discount rate for the deposits " $\mathrm{X}$ " in subsequent annual periods

\begin{tabular}{|l|c|c|c|c|c|c|c|c|c|c|c|c|}
\hline \multicolumn{1}{|c|}{ Rok } & $\mathrm{R} 1$ & $\mathrm{R} 2$ & $\mathrm{R} 3$ & $\mathrm{R} 4$ & $\mathrm{R} 5$ & $\mathrm{R} 6$ & $\mathrm{R} 7$ & $\mathrm{R} 8$ & $\mathrm{R} 9$ & $\mathrm{R} 10$ & $\mathrm{R} 11$ & $\mathrm{R} 12$ \\
\hline$\left(^{*}\right)$ Faza & $\mathrm{U}$ & $\mathrm{U}$ & $\mathrm{U}$ & $\mathrm{U}$ & $\mathrm{P}$ & $\mathrm{P}$ & $\mathrm{P}$ & $\mathrm{P}$ & $\mathrm{P}$ & $\mathrm{P}$ & $\mathrm{P}$ & $\mathrm{P}$ \\
\hline Stopa RADR & $15,7 \%$ & $15,7 \%$ & $15,7 \%$ & $15,7 \%$ & $12,8 \%$ & $12,8 \%$ & $12,8 \%$ & $12,8 \%$ & $12,8 \%$ & $12,8 \%$ & $12,8 \%$ & $12,8 \%$ \\
\hline Rok & $\mathrm{R} 13$ & $\mathrm{R} 14$ & $\mathrm{R} 15$ & $\mathrm{R} 16$ & $\mathrm{R} 17$ & $\mathrm{R} 18$ & $\mathrm{R} 19$ & $\mathrm{R} 20$ & $\mathrm{R} 21$ & $\mathrm{R} 22$ & $\mathrm{R} 23$ & $\mathrm{R} 24$ \\
\hline$\left(^{*}\right)$ Faza & $\mathrm{P}$ & $\mathrm{P}$ & $\mathrm{P}$ & $\mathrm{P}$ & $\mathrm{P}$ & $\mathrm{P}$ & $\mathrm{P}$ & $\mathrm{P}$ & $\mathrm{P}$ & $\mathrm{P}$ & $\mathrm{P}$ & $\mathrm{P}$ \\
\hline Stopa RADR & $11,8 \%$ & $11,8 \%$ & $11,8 \%$ & $11,8 \%$ & $11,8 \%$ & $13,2 \%$ & $13,2 \%$ & $13,2 \%$ & $13,2 \%$ & $12,0 \%$ & $13,1 \%$ & $14,5 \%$ \\
\hline Rok & $\mathrm{R} 25$ & $\mathrm{R} 26$ & $\mathrm{R} 27$ & $\mathrm{R} 28$ & $\mathrm{R} 29$ & $\mathrm{R} 30$ & $\mathrm{R} 31$ & $\mathrm{R} 32$ & $\mathrm{R} 33$ & $\mathrm{R} 34$ & $\mathrm{R} 35$ & \\
\hline$\left(^{*}\right)$ Faza & $\mathrm{P}$ & $\mathrm{P}$ & $\mathrm{P}$ & $\mathrm{P}$ & $\mathrm{P}$ & $\mathrm{P}$ & $\mathrm{P}$ & $\mathrm{P}$ & $\mathrm{L}$ & $\mathrm{L}$ & $\mathrm{L}$ & \\
\hline Stopa RADR & $15,8 \%$ & $15,8 \%$ & $15,8 \%$ & $12,8 \%$ & $12,4 \%$ & $12,4 \%$ & $12,4 \%$ & $12,4 \%$ & $5,8 \%$ & $5,8 \%$ & $6,1 \%$ & \\
\hline
\end{tabular}

(*) Faza realizacji projektu.

$\mathrm{U}$ - udostępnienie, $\mathrm{P}$ - wydobycie (produkcja węgla handlowego), L - likwidacja. 
- kategorie rozpoznania zasobów złoża „X” oraz błędy przypisane do danej kategorii rozpoznania (Nieć 1982),

- przyjęte harmonogramy eksploatacji i wynikające zeń ilości zasobów zalegających w poszczególnych pokładach przewidzianych do wybrania.

Szczegółowe zestawienie stopy RADR w kolejnych okresach analizy zaprezentowano w tabeli 6 (przyjęto założenie upraszczające, że stopa RADR nie będzie uwzględniać dodatkowych ryzyk związanych z systemem eksploatacji, czy też czynnikami makroekonomicznymi).

\section{Koszty składowania odpadów}

Biorąc pod uwagę Rozporządzenie Ministra Środowiska wraz z obowiązującymi na rok 2015 stawkami przyjęto, że całość odpadów będzie pochodzić z flotacyjnego wzbogacania węgla i będzie objęta uśrednioną stawką 13,0 zł/Mg.

\section{Koszty likwidacji kopalni}

Koszty likwidacji kopalni oszacowano na 55,3 mln zł. W modelu kwota ta stanowi teoretyczną, pieniężną wartość Funduszu Likwidacji Zakładu Górniczego (FLZG) na moment wyceny.

Założono ponadto, że odpisy będą stanowić oprocentowany kapitał, a narosłe odsetki powiększą wartość łącznych przychodów finansowych. Oprocentowanie środków zgromadzonych na FLZG przyjęto na poziomie 3,0\% (nominalnie).

\section{Wartość rezydualna}

Wartość rezydualna w modelu wyceny stanowiła teoretyczną wartość niezamortyzowanych aktywów trwałych (różnica pomiędzy łącznym poziomem nakładów inwestycyjnych i skumulowanej amortyzacji) oraz kapitału obrotowego netto w ostatnim okresie analizy.

Jej wartość zdyskontowana została oszacowana na 99,1 mln zł i powiększała poziom łącznych przepływów pieniężnych.

\section{Opłata eksploatacyjna}

Do obliczeń przyjęto opłatę eksploatacyjną na poziomie 2,31 zł za Mg wydobytego węgla. Została ona uwzględniona w kosztach operacyjnych.

\section{Podatek dochodowy i inne podatki}

Stawkę podatku dochodowego w całym okresie analizy przyjęto na poziomie $19,0 \%$, $i$ był on liczony jedynie od dodatniej podstawy do opodatkowania.

Założono, że podatek VAT (należny; naliczony) będzie w całym okresie oceny zbilansowany i wyzerowany, a jego szczegółowa projekcja została wyłączona z kalkulacji.

\section{Dywidenda i wypłaty z zysku netto}

Założono, że w projekcjach finansowych nie będą kalkulowane żadne wypłaty z wypracowywanego zysku netto. 


\section{Wyniki symulacji}

W tabeli 7 zaprezentowano wyniki przeprowadzonej symulacji. Jak już wspominano, dla zmiennych wartości współczynnika uzysku węgla netto (WUWN) wyliczano przyjęte miary wartości i ryzyka oraz kilka pokrewnych miar ekonomiczno-finansowych. Tabele te prezentują wyniki dla wartości WUWN zmieniającego się co 10,0 pkt. proc., w przedziale od 50,0 do $100,0 \%$. Rezultaty obliczeń, w ujęciu graficznym, zostały zaprezentowane z kolei na rysunku 5.

W tabeli 7, w wierszu 10, przedstawiono całkowite gotówkowe koszty operacyjne za 35 kolejnych okresów obliczeniowych, po uwzględnieniu wszystkich założeń i korekt kosztów, przy danym poziomie WUWN. Z kolei w wierszu 11, dla porównania, zestawiono koszty operacyjne oszacowane w tym samym okresie na podstawie kosztów bazowych wydobycia urobku (134,2 zł/Mg urobku).

Analizując zarówno tabelę 7 jak i rysunek 6 można zauważyć, że dodatnia NPV (dla przyjętych bazowych wartości kluczowych zmiennych decyzyjnych) występuje dla wartości współczynnika uzysku węgla netto w przedziale 75,0-80,0\% (dokładnie 77,0\%), co odpowiada ilości powstających odpadów rzędu $57,6-76,8 \mathrm{mln} \mathrm{Mg}$. Dla WUWN na poziomie $80,0 \%$, IRR jest wyższa od średniej efektywnej stopy dyskontowej ustalonej w modelu wyceny $(\mathrm{RADR}=12,7 \%$ vs $\mathrm{IRR}=12,8 \%)$.

Przy poziomie WUWN rzędu 60,0\%, skumulowany EBIT osiąga wartość 3,34 mld zł.

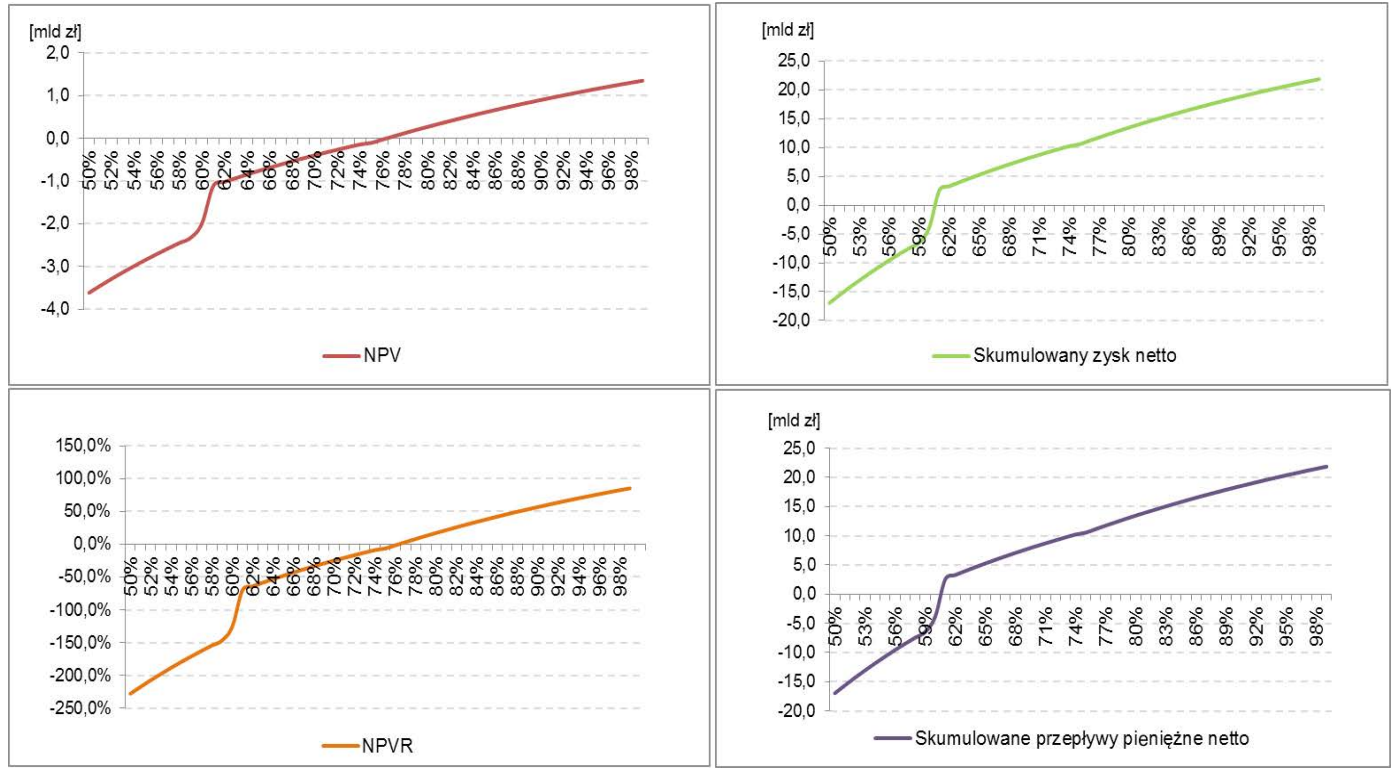

Rys. 6. Wyniki oceny efektywności ekonomicznej złoża „X” w funkcji WUWN; scenariusz bazowy. Na osi poziomej „x” odłożono kolejne wartości WUWN [\%]

Fig. 6. The result of the economic assessment of the deposit " $\mathrm{X}$ " as a function of the coal yield; baseline scenario. "x" axis - the following values of WUWN [\%] 
Tabela 7. Wyniki oceny efektywności ekonomicznej i kosztów gospodarki skałą płonną dla złoża „X”

Table 7. The results of economic assessment and costs estimation of waste rock for the deposits " $\mathrm{X}$ "

\begin{tabular}{|c|c|c|c|c|c|c|c|c|c|}
\hline \multirow{2}{*}{ Lp. } & \multirow{2}{*}{ Wyszczególnienie } & \multirow{2}{*}{ J.m. } & \multicolumn{7}{|c|}{ Uzysk węgla netto [współczynnik zanieczyszczenia urobku] } \\
\hline & & & $50,0 \%$ & $60,0 \%$ & $70,0 \%$ & $75,0 \%$ & $80,0 \%$ & $90,0 \%$ & $99,0 \%$ \\
\hline 1. & NPV & {$[\mathrm{mln} \mathrm{zt}]$} & $-3613,1$ & $-1988,8$ & $-393,1$ & $-103,3$ & 273,3 & 901,2 & 1352,4 \\
\hline 2. & IRR & {$[\%]$} & N/A & N/A & N/A & N/A & $12,8 \%$ & $16,6 \%$ & $19,4 \%$ \\
\hline 3. & NPVR & {$[\%]$} & $-227,9 \%$ & $-125,5 \%$ & $-24,8 \%$ & $-6,5 \%$ & $17,2 \%$ & $56,9 \%$ & $85,3 \%$ \\
\hline 4. & (*) EBIT & {$[\mathrm{mln} \mathrm{zl}]$} & $-8194,4$ & 3344,4 & 17474,7 & 20346,5 & 23905,0 & 29835,6 & 34148,7 \\
\hline 5. & (*) Zysk netto & {$[\mathrm{mln} \mathrm{zt}]$} & $-16943,3$ & $-3810,8$ & 8224,1 & 10576,2 & 13498,6 & 18365,6 & 21887,0 \\
\hline 6. & $\begin{array}{l}(*) \text { Przepływy } \\
\text { pieniężze netto }\end{array}$ & {$[\mathrm{mln} \mathrm{zt}]$} & $-16968,8$ & $-3836,4$ & 8198,5 & 10550,6 & 13473,0 & 18340,0 & 21861,4 \\
\hline 7. & Nakłady inwestycyjne & {$[\mathrm{mln} \mathrm{z}]$} & 7697,5 & 7697,5 & 7697,5 & 7697,5 & 7697,5 & 7697,5 & 7697,5 \\
\hline 8. & $\begin{array}{l}\text { (*) Produkcja węgla } \\
\text { handlowego }\end{array}$ & {$[\mathrm{mln} \mathrm{Mg}]$} & 230,3 & 230,3 & 230,3 & 230,3 & 230,3 & 230,3 & 230,3 \\
\hline 9. & (*) Ilość odpadów & {$[\mathrm{mln} \mathrm{Mg}]$} & 230,3 & 153,5 & 98,7 & 76,8 & 57,6 & 25,6 & 2,3 \\
\hline 10. & $\begin{array}{l}\text { (*) Gotówkowe koszty } \\
\text { operacyjne (symulacja) }\end{array}$ & {$[\mathrm{mln} \mathrm{z}]$} & 69857,6 & 58318,8 & 44188,5 & 41316,7 & 37758,2 & 31827,6 & 27514,5 \\
\hline 11. & $\begin{array}{l}\text { (*) Gotówkowe koszty } \\
\text { operacyjne (bazowe) }\end{array}$ & {$[\mathrm{mln} \mathrm{z}]$} & 62536,8 & 51834,7 & 44190,4 & 41132,7 & 38457,2 & 33998,0 & 30754,9 \\
\hline 12. & $\begin{array}{l}\text { (*) Gotówkowe koszty } \\
\text { wydobycia (dołowe) }\end{array}$ & {$[\mathrm{mln} \mathrm{zl}]$} & 60861,2 & 50717,7 & 43472,3 & 40574,2 & 38038,3 & 33811,8 & 30738,0 \\
\hline 13. & $\begin{array}{l}(*) \text { Koszty produkcji } \\
\text { węgla handlowego }\end{array}$ & {$[\mathrm{mln} \mathrm{z}]$} & 27125,4 & 27727,7 & 28357,4 & 28683,1 & 29016,4 & 29706,7 & 30356,6 \\
\hline 14. & $\begin{array}{l}\text { (*) Koszty wydobycia } \\
\text { skały płonnej }\end{array}$ & {$[\mathrm{mln} \mathrm{zl}]$} & 33735,8 & 22990,0 & 15114,9 & 11891,0 & 9021,9 & 4105,1 & 381,4 \\
\hline 15. & $\begin{array}{l}(*) \text { Koszty wydobycia } \\
\text { skały płonnej ze ścian }\end{array}$ & {$[\mathrm{mln} \mathrm{zl}]$} & 22013,0 & 15001,2 & 9862,6 & 7759,0 & 5886,9 & 2678,6 & 248,8 \\
\hline 16. & $\begin{array}{l}(*) \text { przerostów } \\
\text { i przybierek }\end{array}$ & {$[\mathrm{mln} \mathrm{z}]$} & 20827,6 & 14193,4 & 9331,6 & 7341,2 & 5569,9 & 2534,4 & 235,4 \\
\hline 17. & $(*)$ opadu stropu & {$[\mathrm{mln} z \mathrm{z}]$} & 1185,4 & 807,8 & 531,1 & 417,8 & 317,0 & 144,2 & 13,4 \\
\hline 18. & $\begin{array}{l}(*) \text { Koszty wydobycia } \\
\text { skały płonnej } \\
\text { z chodników }\end{array}$ & {$[\mathrm{mln} \mathrm{zl}]$} & 11722,8 & 7988,8 & 5252,3 & 4132,0 & 3135,0 & 1426,5 & 132,5 \\
\hline 19. & $\begin{array}{l}\text { (*) Koszty skały płonnej } \\
\text { „powierzchnia” }\end{array}$ & {$[\mathrm{mln} \mathrm{z} ł]$} & 1675,5 & 1117,0 & 718,1 & 558,5 & 418,9 & 186,2 & 16,9 \\
\hline
\end{tabular}

$(*)$ - wyniki łączne (skumulowane) w okresie analizy (35 kolejnych okresów rocznych). Źródło: wyniki symulacji, opracowanie własne 
Sumaryczny zysk netto osiąga wartość dodatnią (2,59 mld zł) powyżej WUWN wynoszącego $61,0 \%$.

Należy podkreślić, że istotny wpływ na uzyskane wartości wynikowych zmiennych zdyskontowanych ma przyjęta stopa RADR.

W przebiegu krzywych NPV, NPVR, skumulowanego zysku netto i skumulowanych przepływów pieniężnych widoczne są skokowe zmiany wartości. Wynikają one z zaimplementowanych formuł korygujących koszty operacyjne w prognozie długoterminowej.

Wrażliwość wybranych wynikowych zmiennych ekonomiczno-finansowych została zaprezentowana $\mathrm{z}$ kolei $\mathrm{w}$ tabeli 8 .

Tabela 8. Wyniki analizy wrażliwości wybranych paramentów na zmianę poziomu współczynnika uzysku węgla netto w zakresie 50,0-99,0\%

Table 8. The results of sensitivity analysis of the chosen parameters and coal yield in the range of $50-99 \%$

\begin{tabular}{|l|c|c|c|c|c|c|c|c|}
\hline \multirow{2}{*}{ Wyszczególnienie } & \multirow{2}{*}{ J.m. } & \multicolumn{7}{|c|}{ Współczynnik uzysku węgla netto [\%] } \\
\cline { 3 - 10 } & & $50,0 \%$ & $60,0 \%$ & $70,0 \%$ & $75,0 \%$ & $80,0 \%$ & $90,0 \%$ & $99,0 \%$ \\
\hline NPV & {$[\%]$} & 3498,7 & 1925,8 & 380,6 & 100,0 & $-264,7$ & $-872,7$ & $-1309,5$ \\
\hline$(*)$ EBIT & {$[\%]$} & $-40,3$ & 16,4 & 85,9 & 100,0 & 117,5 & 146,6 & 167,8 \\
\hline$(*)$ Zysk netto & {$[\%]$} & $-160,2$ & $-36,0$ & 77,8 & 100,0 & 127,6 & 173,7 & 206,9 \\
\hline $\begin{array}{l}(*) \text { Przepływy } \\
\text { pieniężne netto }\end{array}$ & {$[\%]$} & $-160,8$ & $-36,4$ & 77,7 & 100,0 & 127,7 & 173,8 & 207,2 \\
\hline $\begin{array}{l}(*) \text { Koszty operacyjne } \\
\text { (sym.) }\end{array}$ & {$[\%]$} & 169,1 & 141,2 & 107,0 & 100,0 & 91,4 & 77,0 & 66,6 \\
\hline $\begin{array}{l}(*) \text { Koszty wydobycia } \\
\text { skały płonnej }\end{array}$ & {$[\%]$} & 283,7 & 193,3 & 127,1 & 100,0 & 75,9 & 34,5 & 3,2 \\
\hline
\end{tabular}

(*) - wyniki łączne (skumulowane) w okresie analizy (35 kolejnych okresów rocznych).

Została ona określona poprzez odniesienie wartości obliczeniowej (przy danym WUWN) do bazowej, oszacowanej przy bazowym WUWN (74,6\%). Przykładowo można zauważyć, że spadek WUWN o 5,0 pkt. proc. do poziomu 70,0\% powoduje spadek NPV o $380,6 \%$, EBIT o $85,9 \%$, zysku netto o 77,8\%, czy kosztów wydobycia odpadów rzędu 127,1\%.

Zależności tak ustalone nie wykazują liniowości.

Interesująco przedstawia się natomiast problem skali kosztów gospodarki skałą płonną w całym okresie analizy, co w ujęciu graficznym przestawiono na rysunku 7.

Można zauważyć, że dla wartości WUWN 60,0\% uwzględnienie dodatkowych założeń w prognozie kosztów może skutkować podwyższeniem kosztów operacyjnych przedsięwzięcia inwestycyjnego o blisko 6,48 mld zł łącznie dla 35 kolejnych okresów analizy. Natomiast w przypadku eksploatacji złoża przy średnim WUWN rzędu 85,0\% różnica w poziomie możliwych do zrealizowania kosztów może być niższa nawet o 1,48 mld zł. 


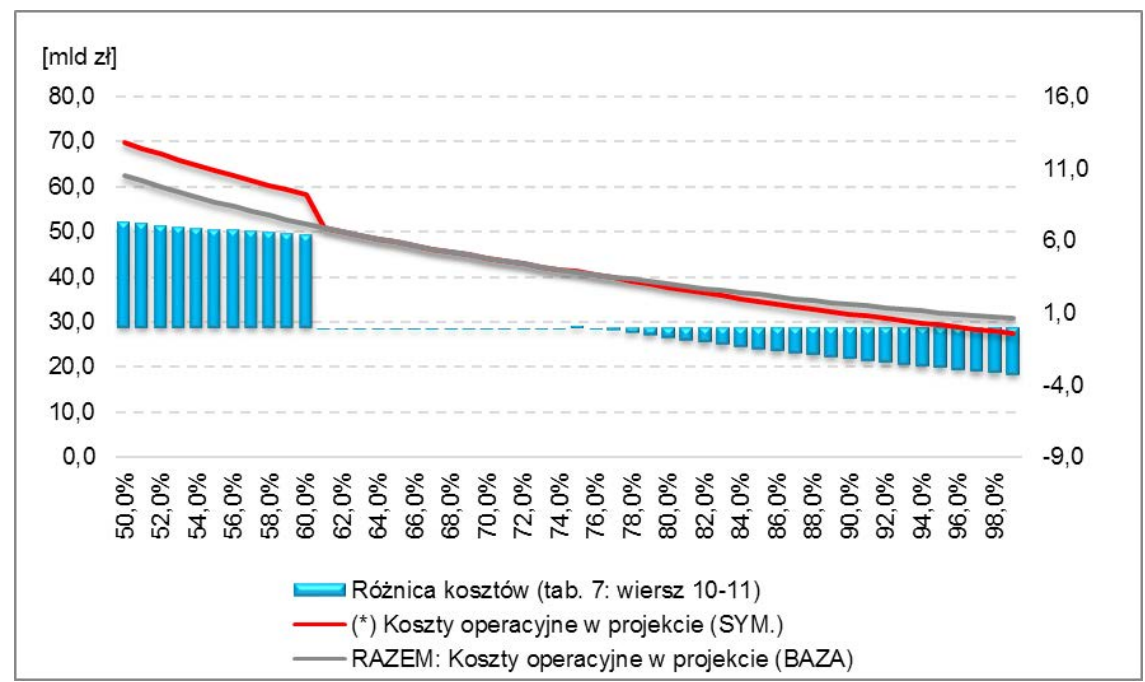

Rys. 7. Koszty wydobycia skały płonnej: porównanie kosztów w scenariuszu bez i po uwzględnieniu korekty kosztów operacyjnych z tytułu zmienności WUWN na przykładzie złoża „X”.

Lewa oś - koszty operacyjne; prawa oś - różnica pomiędzy kosztami symulowanymi a bazowymi w projekcie. Oś odciętych - kolejne wartości WUWN

Fig. 7. The costs of rock waste exploitation: a comparison between the scenario with and without adjustments of operating costs due to variability of coal yield on the example of the deposit " $\mathrm{X}$ ".

Left axis - operating costs; right axis - the difference between the simulated and the underlying costs in the project. " $\mathrm{x}$ " axis - the next values of WUWN

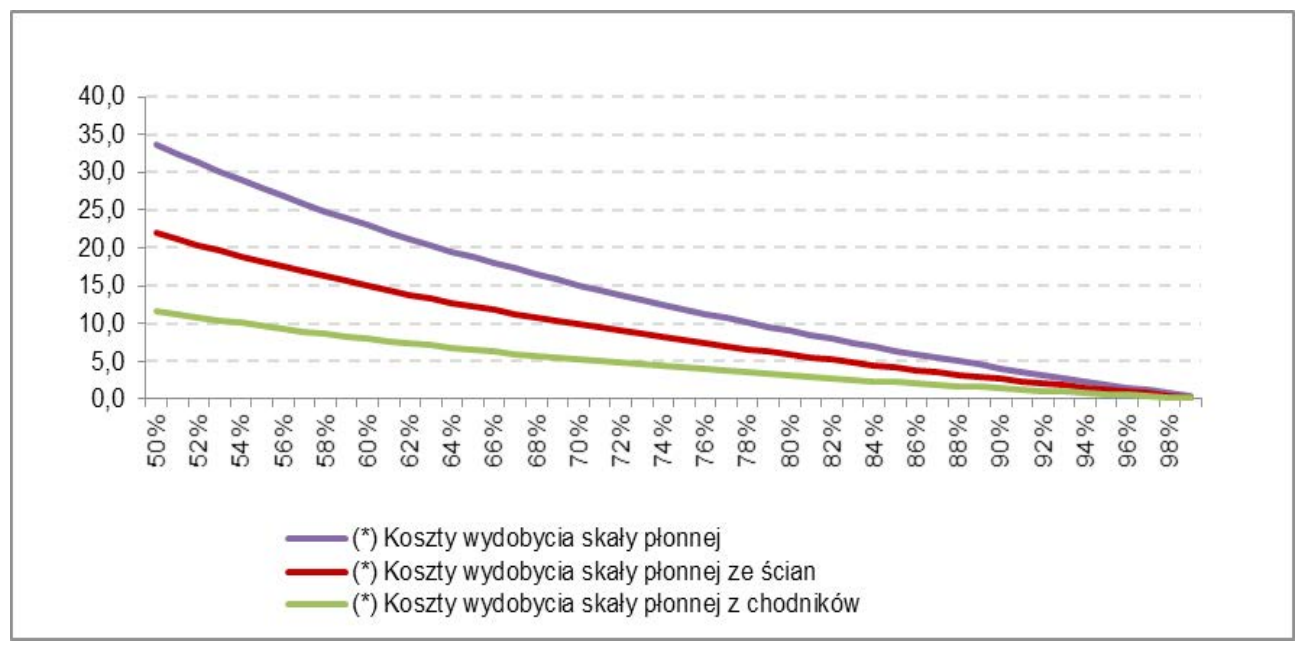

Rys. 8. Całkowite koszty urabiania skały płonnej według źródeł jej powstawania na przykładzie złoża „X”; scenariusz bazowy

Fig. 8. Total costs of waste rock exploitation by sources of impurities on the example of the deposit "X"; baseline scenario 
Z kolei wykres 8 przedstawia zmienność kosztów urabianej skały płonnej, biorąc pod uwagę źródła jej pochodzenia. Dla skrajnie niskich wartości WUWN koszty te mogą przekraczać 33,7 mld zł w całym okresie istnienia analizowanej kopalni (35 okresów), a udział kosztów skały płonnej może sięgać nawet 48,3\% całości kosztów operacyjnych (tab. 9). Przy bazowym poziomie WUWN (74,6\%) udział kosztów skały płonnej w całkowitych kosztach operacyjnych wynosi około $28,7 \%$.

Wraz ze wzrostem WUWN, relacje te zmieniają się; rośnie udział całkowitych kosztów wydobycia węgla, spadają natomiast koszty wydobycia skały płonnej.

Analizując tabelę 9 można ponadto zauważyć, że udział kosztów wydobycia skały płonnej ze ścian jest blisko 1,9 razy wyższy niż odpadów pochodzących z wyrobisk chodnikowych.

Koszty zagospodarowania odpadów na powierzchni nie przekraczają 5,0\% całości kosztów gospodarki skałą płonną i mają znaczenie marginalne.

Tabela 9. Wyniki oceny efektywności ekonomicznej i kosztów powstającej skały płonnej dla różnych wartości WUWN dla złoża „X”

Table 9. The results of economic assessment and rock waste costs for different values of coal yield for the deposit "X"

\begin{tabular}{|l|r|r|r|r|r|r|c|}
\hline \multicolumn{1}{|c|}{ Wyszczególnienie } & $50,0 \%$ & $60,0 \%$ & $70,0 \%$ & $75,0 \%$ & $80,0 \%$ & $90,0 \%$ & $99,0 \%$ \\
\hline $\begin{array}{l}\text { Udział kosztów (*) operacyjnych } \\
\text { w projekcie (SYM.) }\end{array}$ & $100,0 \%$ & $100,0 \%$ & $100,0 \%$ & $100,0 \%$ & $100,0 \%$ & $100,0 \%$ & $100,0 \%$ \\
\hline $\begin{array}{l}\text { Udział kosztów (*) urabiania skały } \\
\text { płonnej }\end{array}$ & $48,3 \%$ & $39,4 \%$ & $34,2 \%$ & $28,8 \%$ & $23,9 \%$ & $12,9 \%$ & $1,4 \%$ \\
\hline $\begin{array}{l}\text { Udział kosztów (*) wydobycia skały } \\
\text { płonnej ze ścian }\end{array}$ & $65,3 \%$ & $65,3 \%$ & $65,3 \%$ & $65,3 \%$ & $65,3 \%$ & $65,3 \%$ & $65,3 \%$ \\
\hline $\begin{array}{l}\text { Udział kosztów (*) wydobycia skały } \\
\text { płonnej z chodników }\end{array}$ & $34,7 \%$ & $34,7 \%$ & $34,7 \%$ & $34,7 \%$ & $34,7 \%$ & $34,7 \%$ & $34,7 \%$ \\
\hline $\begin{array}{l}\text { Udział kosztów (*) skały płonnej } \\
\text {,powierzchnia" }\end{array}$ & $5,0 \%$ & $4,9 \%$ & $4,8 \%$ & $4,7 \%$ & $4,6 \%$ & $4,5 \%$ & $4,4 \%$ \\
\hline
\end{tabular}

(*) - wyniki łączne (skumulowane) w okresie analizy (35 kolejnych okresów rocznych).

\section{Podsumowanie i wnioski}

Przedstawione badania symulacyjne wskazują na istotne znacznie kosztów skały płonnej w całości kosztów operacyjnych związanych z wydobyciem węgla w kopalniach podziemnych.

Skala kosztów wydaje się uzasadniać poszukiwania rozwiązań zmierzających do ograniczania ilości odpadów powstających na dole kopalni na rzecz możliwie „czystej” eks- 
ploatacji. Przeprowadzona analiza wskazuje na silny związek możliwych do osiągnięcia oszczędności w kosztach z tytułu ograniczania skali wydobywanych odpadów skalnych.

Jest jednak faktem, że problem efektywnego sterowania wydobyciem jest silnie ograniczony specyfiką procesu eksploatacji, warunkami geologiczno-górniczymi zalegania pokładów przeznaczonych do wybierania, czy też regulacjami prawnymi w tym zakresie.

Wobec braku sprawdzonych rozwiązań, ograniczanie „problemu” skały płonnej na dole sprowadza się w praktyce do prowadzenia prac wydobywczych w pokładach o możliwie dużej miąższości węgla, niespękanych, względnie słabo zuskokowanych i płytko zalegających. Znajdywanie takich warunków geologiczno-górniczych jest coraz bardziej skomplikowane, a niejednokrotnie wręcz niemożliwe.

Niemniej jednak, w chwili obecnej, ze względu na trudną sytuację polskiego górnictwa węgla kamiennego uzasadnione wydaje się być uruchamianie badań pilotażowych i eksperymentów mogących $\mathrm{w}$ przyszłości przerodzić się w dojrzałe rozwiązanie wspierające poprawę kosztów procesu wydobywczego. Kopalnie winny podejmować uzasadnione wysiłki zmierzające do zmiany aktualnego stanu rzeczy, ponieważ problem pogarszającej się efektywności wydobycia będzie narastał podczas eksploatacji zasobów w niskich pokładach głębiej zalegających.

Przedstawione wyniki pokazują, że urabianie kamienia może być i jest niejednokrotnie bardziej kosztowne niż samego węgla.

Prowadzona w kopalniach ewidencja kosztów wydobycia węgla nie pozwala jednak na natychmiastowy dostęp do odpowiednich wniosków, chociaż zauważalny jest wzrost świadomości i skali problemu eksploatacji węgla przy udziale dużych ilości odpadów skalnych. Ostatecznie o „być albo nie być” kopalń w dłuższej perspektywie będzie rozstrzygał rygorystyczny rachunek zyskowności prowadzonej działalności gospodarczej.

Kierunek dalszych badań modelowych winien zmierzać do bardziej precyzyjnego uwzględniania różnych czynników, mogących wpływać na efektywność i rozdział kosztów wydobycia różnego rodzaju urobku w kopalniach. Kluczowe znaczenie posiada zwiększenie precyzji modelowania ilości skały płonnej w relacji do zmiennych parametrów złożowych. Rekomendowanym podejściem staje się rzetelne monitorowanie kosztów w miejscach ich powstawania na poziomie poszczególnych procesów.

W pracy dokładność modelowania kosztów wydobycia węgla i skały płonnej limitowana jest prawidłowością agregacji kosztów do poszczególnych centrów kosztów. Ich liczba winna być stopniowo rozszerzona, obejmując dodatkowo kluczowe procesy wsparcia. Traktowanie pojedynczych ścian, czy też pól eksploatacyjnych jako samodzielnych centrów odpowiedzialności w „systemie usługowym” może zwiększyć stopień kontroli i monitoringu kosztów - również skały płonnej - na etapie budżetowania i później rozliczania.

Praca finansowana z badań statutowych Instytutu Gospodarki Surowcami Mineralnymi i Energia Polskiej Akademii Nauk. 


\title{
LITERATURA
}

Blaschke, W. 2005. Określenie wartości mułów węglowych zdeponowanych w osadnikach ziemnych. Zeszyty Naukowe Wydziału Budownictwa i Inżynierii Środowiska, Inżynieria Środowiska 22, s. 345-358.

Czopek, K. 2002. Metodologia analizy kosztu jednostkowego wydobycia. Wiadomości Górnicze R. $53 \mathrm{nr} 12$, s. 512-518.

Damodaran, A. 2007. Finanse korporacyjne. Teoria i praktyka. Wydanie II. Wyd. Onepress.

Frączek, R. 1992. Zagadnienia opłacalności różnych sposobów utylizacji skały płonnej w kopalniach węgla kamiennego. Przegląd Górniczy 6, s. 15-17.

Góralczyk, S. i in. red. 2011. Gospodarka surowcami odpadowymi z węgla kamiennego. Warszawa: Wyd. IMBiGS.

Grudziński, Z. 2009. Propozycje struktur cenowych dla węgla kamiennego energetycznego i węgla brunatnego. Polityka Energetyczna - Energy Policy Journal 12 (2/2), s. 159-171.

Jajuga, K. i Jajuga, T. 2000. Inwestycje, Warszawa: Wyd. PWN.

Karbownik A.2007. Zarządzanie projektami w przedsiębiorstwie górniczym - część 10. Planowanie projektu. Wiadomości Górnicze 12, s. 684-686;

Kulczycka i in. 2014 - Kulczycka, J., Uberman, R. i Cholewa, M. 2014. Analiza kosztów i korzyści zagospodarowania odpadów z górnictwa węgla kamiennego [W:] A. Barteczek, A. Rączaszek, Studia ekonomiczne - Polityka gospodarcza w okresie transformacji i kryzysu. Katowice, s. 272-282.

Kustra, A. i Sierpińska, M. 2013. Realizacja funkcji budżetowania i kontroli w cyklu życia pola eksploatacyjnego w kopalni węgla kamiennego. Przegląd Górniczy t. 69, nr 9, s. 94-98.

Magda i in. - Magda, R., Woźny, T., Kowalczyk, B., Głodzik, S. i Gryglik, D. 2002. Racjonalizacja modelu i wielkości kopalń węgla kamiennego w warunkach gospodarczych początku XXI wieku, Kraków: Wyd. AGH.

Nieć, M. 1982. Geologia kopalniana. Warszawa: Wyd. Geologiczne.

Turek, M. 2013. System zarządzania kosztami w kopalni węgla kamiennego w cyklu istnienia wyrobiska wybierkowego. Warszawa: Wyd. Difin.

Włoszek, J. 2002. Deponowanie odpadów w podziemnych kopalniach węgla kamiennego podczas eksploatacji z zawałem stropu. Kraków: Wyd. IGSMiE PAN.

OCENA KOSZTÓW GOSPODARKI SKALĄ PLONNĄ W FUNKCJI

ZMIENNEGO POZIOMU WSPÓLCZYNNIKA UZYSKU WĘGLA NETTO

NA PRZYKLADZIE KOPALNI WEGLA KAMIENNEGO

\author{
Słowa kluczowe \\ górnictwo węgla kamiennego, ocena efektywności ekonomicznej, \\ metody dyskontowe, ocena kosztów powstającej skały płonnej, \\ współczynnik uzysku węgla netto, model symulacyjny
}

\section{Streszczenie}

Istotnym aspektem prawidłowo prowadzonego procesu zarządzania $\mathrm{w}$ kopalniach jest ocena potencjału złoża, jego optymalnego udostępnienia, zagospodarowania i eksploatacji. W ten zakres zagadnień włączają się niewątpliwie właściwie rozumiane aspekty kosztów urabiania skały płonnej, która towarzyszy procesowi wydobycia kopalin użytecznych.

Analizując dane dotyczące gospodarki skałą płonną w górnictwie węgla kamiennego w Polsce można zauważyć, że od roku 2010 ponad 30,0\% całości wydobycia stanowią odpady wydobyw- 
cze. Na tle statystyki wydobycia węgla od roku 2003 ujawnia się ponadto rosnący trend w tym zakresie.

W artykule postawiono tezę, iż urabianie i wydobywanie skały płonnej istotnie i negatywnie wpływa na efektywność prowadzonego wydobycia oraz łączny poziom kosztów w kopalniach węgla kamiennego.

Artykuł stanowi próbę weryfikacji i kwantyfikacji realnych kosztów skały płonnej w przygotowanym na potrzeby symulacji modelu ekonomiczno-finansowym przykładowej kopalni węgla kamiennego w całym cyklu życia omawianego projektu.

W celu zweryfikowania postawionych tez badawczych zbudowano dedykowany model oceny, bazujący na metodach dyskontowych, w którym analizowano koszty skały płonnej pochodzącej zarówno z wyrobisk chodnikowych jak i ścian wydobywczych. Na jego podstawie zweryfikowano, oprócz samej oceny efektywności ekonomicznej nowego złoża, wpływ zmiennej ilości (i kosztów) skały płonnej na kluczowe mierniki (wskaźniki) ekonomiczno-finansowe projektu. Wpływ kosztów skały płonnej badano w zakresie współczynnika uzysku węgla netto (WUWN) od 50\% do 99\%.

Analiza potwierdziła, że dla skrajnie niskich wartości WUWN koszty urabiania skały płonnej mogą sięgać 48,3\% całości kosztów operacyjnych w nowo projektowanej kopalni. Przy bazowym poziomie WUWN $(74,6 \%)$ udział kosztów skały płonnej w całkowitych kosztach operacyjnych wynosi blisko $28,7 \%$.

Dodatnia NPV, dla przyjętych bazowych wartości kluczowych zmiennych decyzyjnych, występuje dopiero przy poziomie WUWN w przedziale 77,0-80,0\%. Dopiero przy wartości WUWN rzędu $80,0 \%$, IRR jest wyższa od średniej efektywnej stopy dyskontowej w projekcie (RADR $=12,7 \%$ vs $\operatorname{IRR}=12,8 \%)$

Istotny wpływ na uzyskane wartości zmiennych zdyskontowanych ma przyjęta stopa RADR.

Przedstawione wyniki pokazują, że urabianie kamienia może być i jest niejednokrotnie bardziej kosztowne niż samego węgla.

\section{EVALUATION OF THE WASTE ROCK MANAGEMENT COSTS AS A FUNCTION OF THE LEVEL OF COAL YIELD ON THE EXAMPLE OF THE COAL MINE}

$$
\text { Key words }
$$

coal mining, economic assessment, discount methods, waste rock costs estimation, coal yield, simulating model

\section{Abstract}

An important aspect of an ongoing management process in the mines is to assess the potential of the deposit, its optimal development and its exploitation. This range of issues will undoubtedly cover properly the understood "problem" of waste rock management costs, which accompanies the process of mineral resources exploitation.

When analysing the data of waste rock management in the Polish coal mining industry, it can be noted that since 2010 more than $30.0 \%$ of total production is represented by extractive waste. Since 2003 an upward trend has also been observed against the coal mining statistics. 
The thesis of the article reveals an opinion that the effectiveness of the coal mining process is significantly and negatively influenced by the waste rock amount and related costs.

The article attempts to verify and quantify the impact of waste rock on economic effectiveness and operating costs of an exemplary coal mine throughout its life cycle.

For this purpose, a dedicated simulation model was built based on discount methods, which examined the costs of waste rock derived from both the drifts and longwalls. On the basis of simulation, the economic efficiency of new deposits was verified together with the impact of variable quantities (and costs) of waste rock on key economic and financial indicators of the project. The impact of the waste rock costs was tested in the range of coal yield (WUWN) from $50 \%$ to $99 \%$.

The analysis confirmed that for extremely low values of WUWN, waste rock costs could reach $47.1 \%$ of total operating expenses in the analysed mine. At the base level of WUWN (74.6\%), the share of the costs of waste rock in the total operating costs is nearly $28.7 \%$.

A positive NPV, estimated for the basic values of key decision variables, occurs at the level of WUWN in the range of $75-80 \%$. Risk adjusted discount rate has a dominating impact on the obtained results.

For the WUWN at $80.0 \%$, the IRR is higher than the average effective discount rate (RADR = $=12.7 \%$ vs. $\mathrm{IRR}=13.2 \%$ ).

The results show that the exploitation of waste rock can be, and often is, more expensive than the mining of coal. 